\title{
Contents
}

\section{Preface and Acknowledgments ix}

I. Who is Naapi? Sign as First Language 3

$$
\text { 2. Naapi's Name } 30
$$

3. Myth, Legend, and Naapi 72

4. A Different Conceptual Order 94

Appendix: Selected Naapi Stories 130

$$
\begin{array}{cc}
\text { Person's Face } & 130 \\
\text { Lone Woman } & 133 \\
\text { Lone Pine } & \text { I33 } \\
\text { Wheel Game } & \text { I35 } \\
\text { Sliding Place } & \text { I35 }
\end{array}
$$

$\begin{array}{ll}\text { Notes } & 137 \\ \text { Index } & \text { I55 }\end{array}$ 


\section{Chapter 1}

\section{Who Is Naapi?}

Sign as First Language

Retelling Trickster in Naapis Language is an in-depth study of the language of the story cycle of Naapi, who has many names and is most commonly known as "Old Man," a Trickster in Blackfoot oral literature. ${ }^{1}$ This study expands on a land-based genre of stories to discuss how they use the land and environment as a teacher, with Naapi interpreted as myriad expressions of nature's forces. This chapter introduces some of the ways Naapi stories effect language use by the many ways his energy is expressed and stems from the acknowledgment that particular aspects of Naapi's identity are not restricted to his story activities but extend beyond the storied context to describe their source in his actions/personality, breath, expressions, songs, and signs. Naapi's power is partially attributed to the ways the Blackfoot language refers to him and speaks to or with him. Traditional Indigenous Trickster literatures throughout the world are built around characters fundamental to the creation of a particular People, and entire story sequences are built around the creative activity of this entity. Not all Tricksters are the same, nor is the term itself Indigenous. In common with other Algonquian/Algonkian language traditions, Naapi's is a creator of the Blackfoot, and he thus lays the groundwork for other Blackfoot story genres, all of which constitute the body of oral literature that makes the Blackfoot a distinctive People. Trickster stories share in common with other Indigenous communities the universal energy that manifests differently across linguistic similarities and geological or geographical differences. 
Translated directly from the Blackfoot language, sometimes from Plains Sign Language, and drawing additional data from Algonquin studies, this book is a critical collection of Blackfoot language studies analyses complemented with multidisciplinary contributions focused on Blackfoot and Algonquian/Algonkian language and translations. It includes published and unpublished works in an effort to conduct research within a richer context than has previously been attempted for a focused study of how the Blackfoot use language to represent Indigenous understandings of Naapi's role as an energy source and creator. The combination of sources and research questions may provide a model for viable comparisons across Algonquian/Algonkian and Plains Peoples' oral literature traditions.

\section{COMMONALITIES WITH OTHER TRICKSTERS}

Naapi stories outline Blackfoot ecology, cosmology, and philosophy, or what Indigenous Peoples call a "way of life." Blackfoot language use conveys critical information about Blackfoot views on all life forms and about how People can live properly with them. This is evident when comparing Naapi's characteristics, adventures, and escapades to those of other Tricksters: Nanabozho (Ojibwa), Wisakedjak (Cree, Algonquin), Iktomi (Lakota), Kokopelli (Hopi and Ancestral Pueblo), Manitou (Dene), and Glooskap (Wabanaki) comprise a sampling from a diverse group that includes Raven (Kwakiutl, Haida, Athabaska, Bella Bella), Crane, Rabbit, and Coyote. Many more are found throughout other Indigenous Peoples' oral traditions. Much of the research approach regarding Naapi is summed up with the statement "Old Man was also known to other plains-tribes and by different names. Some of these myths are fragmentary and incomplete, but all bear an unmistakable stamp of the primitive and childhood period of Blackfeet history. Others are samples of Indian humour, told as we tell fairy tales and using Old Man for their central figure." ${ }^{2}$

This study is a seminal work on Indigenous language that introduces and develops a unique paradigm based on analyses of the ways these stories are told and the places they mention that highlight landscape features and patterns of the flora and fauna and that focus on the incorporation of all these aspects expressed in Naapi stories. It models a way to understand other Trickster traditions and to connect them to the natural world from which they emerge. Tricksters share similarities in that their origins are mysterious, the stories of which have been told since long ago, and there is a sense that they arose out of or manifested into form, seemingly from air or speech. Often, when they depart, they go in the direction from whence the weather comes. As a result of the unique circumstances that contribute to the different homelands of every Indigenous People considered here, where the weather 
"comes from" for them has varying implications for interpretations of Tricksters; it is the universal life-giving energy that creates life on earth, in whatever form that takes depending on the many options of land and skyscapes. Trickster stories, because their essence is to capture these essential descriptions, have the lead to change constantly and occupy a niche within their Peoples' traditional story paradigms that is similar to Naapi's.

This project began as an assignment to identify key locales to map Naapi stories in a geographic and ideographic sense. Naapi stories occur at the beginning of the Blackfoot creation story order and are among those first told to young children as a way to introduce them to the Blackfoot homeland, their new home. The stories explicitly identify and explain the landscape and those who live on or from it, as well as the several Blackfoot story genres, and each respectively identifies with a series of specific locations and seasons. Hence, when discussing these stories in the Blackfoot language, correct interpretations depend on a story's location and time in the seasonal calendar. Seasonal movement of People and animals is more significant than static references to particular places, and it is time, not a geographic point, that centers stories' meanings. Naapi's language, speech forms, and acts in stories acknowledge the participation of others with whom he interacts, and thus we know him and ultimately ourselves through his experiences because they are all part of the homeland matrix.

\section{“OPPOSITE-SPEAK” AS TRICKSTER ARTFORM}

One of the most prominent and pervasive features of Naapi's speech style in stories is that he frequently counters others, in intent and action and through the use of words or songs. Among a host of other speech-related acts, he implores, begs, demands, threatens, mocks, mimics, and orders others. He also utilizes a mode of interaction that is meant to highlight the opposite of what he says or does, which occurs in Blackfoot sociocultural practices not directly in reference to Naapi. When he is out of control and being blown about by wind, grasping for life at anything that can help him stop and be still, for instance, he catches a lucky break when he gets "caught" by a tree, and this ultimately rescues him from peril. Instead of thanking the tree, however, he decides to punish it while admonishing it for interrupting "his fun." On another occasion, he is dancing wildly and showing off when he accidentally sets the grass plains ablaze and ruins the fancy dance outfit he was showing off to everyone. When he has to take recourse in water to save himself and he ruins his clothing, he pretends that everything is as he planned it, as in he "meant to do that." A key aspect of many of these incidents is that Naapi creates, calls forth, or performs in ways that initiate the calamities he later has to get others' help to "solve" 
or from which he needs to be rescued. Such pointed self-referential orientation is designed to encourage self-analysis and reflection and to highlight communities' role in healing or resolving all those affected by his self-induced mishaps.

The spirit of knowing one's limits and yet balancing them against public pride, ego, or arrogance is always a part of these stories. It is also revealed in other aspects of Blackfoot life, such as when you are expected to say the opposite of what you want to happen: if you want the leader of a sweat not to make it very hot, then you must say you want it hot; if you want the piercings for dancing in the summer ceremonies to not be too deep, you have to ask for a deep cut. You even have to think about how you want to be known, since many names are the reverse of the meaning they intend the listener to understand about the person in question. One of Naapi's many names is Fooled-a-Little, which means just the opposite. Other examples include ways the forces of contrariness and balance override and work out in the end in ceremonial roles, in the use of certain items, and even in directions. ${ }^{3}$ This basic paradigmatic stance of Blackfoot language use can obviously wreak havoc with ideas about having "gotten the message" when listening to stories. This is especially true for translations that interpret the original quite literally, as they will render the exact opposite of what Blackfoot speakers intend.

For the Blackfoot, salient topics, themes, and subjects of language use in reference to or by Naapi include the significance of the Blackfoot language in interpreting elements of stories, kinship between People and other Beings in nature, reciprocity, limitations on excess and rules against abuse, the comedy to be found in mistakes, self-actualization through assisting others, gratitude and generosity, and using language to turn situations inside out, thus inverting or reversing the recipientgiver, abused-abuser, or living-dead relationship for analysis and reflection. Naapi's would-be victims turn out to be much like him and vice versa-the "self" turned "other." Expressions, turns of phrase, salient syllables, and some grammar all play a part in how the Blackfoot use language to create a unique framing of appropriate interaction with the world. Naapi stories demonstrate how to live well by using Naapi's mishaps and misadventures as negative examples and by providing language and images that enable listeners to observe themselves in his misbehavior. Naapi epitomizes chaos and order in a fluctuating, frustratingly unpredictable bundle, and his oppositional stances, in word or deed, are mirrors for everyone else.

There are now diminishing numbers of fluent Blackfoot speakers and even fewer who are familiar with Naapi stories, which once were common knowledge. In addition, like other Indigenous languages, Blackfoot has changed over the past two centuries, so it is imperative to access the earliest forms and stories to investigate lessons in human-animal coexistence and examine how they promote ecological, physical, and spiritual sustainability and resilience simultaneously. This is 
found in Naapi's various names and speech patterns, especially his name calling, self-justifications, excuses, explanations, nicknames, and insults and his back talk in general, which inverts situations and increases the possibility to interpret them with ironic humor and to be involved in his activities-which often turn into full-fledged debacles-that show how Naapi is life itself. Defining Naapi involves understanding how oppositional, interactive, and counterbalancing energies work.

Naapi stories are frequently compared to Aesop's Fables, and many authors assert that every story has a motto. Unfortunately, such views emphasize a view of Naapi as a human-like entity, like that of the other Beings he interacts with, including People. When understood through the ways the Blackfoot use language, in turns of phrase, naming practices, and Naapi's multiple names found across his many stories, it is clear that Naapi is not human and neither are his companions. Rather, they represent energies and entities that create circumstances and moments within which humans can pause to observe their actions, not only with each other but with all of nature. Blackfoot language use beyond Naapi stories reflects this reality of interconnectedness. In common with other Tricksters, Naapi stories perpetuate knowledge and awareness of proper dealings and the nature of human nature in light of what works or what doesn't for all life. The language emphasizes an ecological (i.e., social) context within which to interpret Trickster stories and language.

\section{OF NAAPI'S NATIVE NATURE}

This study is the most extensive and meticulous investigation of traditional Naapi identity through language paradigms thus far conducted. To the uninitiated, Naapi stories seem simple because they focus undue attention on Naapi's actions alone and thus are presented in a fashion that belies their deeper environmental, social, and cosmic lessons. This complex, encompassing, and nuanced analysis of Indigenous language and land-based identity identifies Naapi as a creator of Blackfoot consciousness. Naapi's counterparts in other Algonquian/Algonkian languages and oral traditions function similarly. The Blackfoot have occupied the People's traditional homeland in the northwestern United States and southwestern Canada since unknown times. ${ }^{4}$ Like other Indigenous Peoples in their respective homelands, Blackfoot interactions with the local landscape, climate, seasons, winds, rivers, mountains, plains, flora and fauna, and all the animals who share the homeland are recorded in storied anecdotes. These are collective recollections about the Peoples' origins and about the interrelatedness between People and these other Beings, full Persons, through which the People's relationship with nature is expressed: "The Blackfoot creator is known as Napi, Napiu, or Napioa, according to the dialect spoken by the different tribes of the Blackfoot confederation. Quite extended stories 
are told of how he made the world, and of his adventures ... a time before the creation of the earth as we know it to-day, and treats of an incident in the boyhood of Napi." This discussion of Trickster reviews definitions and analyses of Naapi's name and nature and relevant comparative work on Algonquian/Algonkian or Plains Peoples' studies on these topics. Unfortunately, the literature on Naapi is rife with misnomers, mistakes, and repeated misinterpretations. A study of Naapi's name and its meaning could fill volumes; therefore, the aim here is to review the literature to track what has been lost, first in interpretation and then in comprehension, to discover and reconnect essential elements and to discuss Naapi and Naapi stories to reflect Blackfoot traditions and values as expressed in Naapi stories. The identification of key points about Blackfoot language use helps us reinterpret these stories to discover Naapi's essential nature.

\section{NAAPI'S ANCESTRY AND FUTURITY: EPITOME OF OPPOSITIONAL FORCES}

Naapi stories collected over the past two centuries were recollected by elders who had learned the stories from earlier generations of elders, so that by the time they were written down, their versions of these stories were centuries old. The antiquity of Naapi in the Blackfoot consciousness is long-standing, for example:

The story was related to me by an old Blood chief named Men-es-to-kos, which means "all are his children," though the word is commonly translated "father of many children." Men-es-to-kos is not less than seventy years old, and perhaps much older. He told me that he first heard this tale when he was a small boy, from his greatgrandmother, who at that time was a very old woman - so old that her face was all seamed with wrinkles, and... her eyelids hung down over her eyes so that she could not see. I have not the slightest doubt that the tale was told to me in good faith, and it is so remarkable that I consider it worth putting on record. It was told one night when a number of other old men had been relating stories of early times, many of which referred to the doings of Napi. ${ }^{6}$

One of the most ubiquitous interpretations of Naapi is through Christian tenets, thus the insistence that his actions be divided into "good" versus "bad," as in the following: "Napioa is the Secondary Creator of the Indians. There are two kinds of stories told concerning him. One class reveals him in the character of a good man, and the other class as a bad man. He is not, however, a man, but a supernatural being, able to perform deeds which no human could perform."” Since the Blackfoot, however, refer to other-than-human energies when speaking of Naapi, particularly regarding the creative forces of the landscape, it is said that the "Indians do not know the manner of his birth, nor the place from whence he came. He is still living in a 


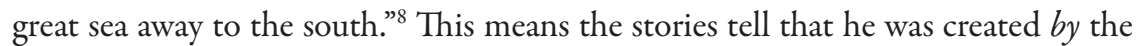
elements rather mysteriously, like all creation, and that he returned to them in one form or another, generally traveling by way of some form of water. His "good" or "bad" effects are thus balanced out over time as the Blackfoot review his creative work.

One extensive exposé on the topic of this balance of energy is as follows:

Thus, in this one [story], the good and bad brothers stand for Light and Darkness; Light overcomes Darkness; God triumphs over the Devil. Whether the original meaning was such is still a mystery... Together the two groups of stories form an engaging pair, both for points of similarity and for contrast... They explained the World's wonders to the Indians, and, as there was no written literature, they served as a history book for them. As we remember these quaint old tales told here in our own Province, it makes it easy for us to understand something about the people who inhabited Alberta so long ago. ${ }^{9}$

Rather than reinforce the "good versus bad" binary invented and advanced by non-Indigenous beliefs, Naapi's "quaint old tales" require reevaluation in light of the environment that gave birth to them and that still informs them if there is to be any chance of understanding them at all. Naapi stories are refined and comprehensive contemplations and redefinitions of the environment writ large, including the atmosphere, climate, and astronomy, and of how People came to live in it-in short, the wonder of creation. Naapi's power is not uncontrolled, nor is it wanton or without reason, as often portrayed in Trickster literature. The presumably malevolent aspects of his personality are interpreted incorrectly, since they should be interpreted as part of a creative matrix of universal energy. Naapi stories also do not offer a discrete or distinct description of People because Naapi frequently inhabits or represents himself through other identities. Analyses of Blackfoot creation stories, including those of Naapi, too often perceive "the rich imagination and high quality of the story teller" ${ }^{10}$ while dismissing the actions described as exaggeration or fantasy and unreal, but Naapi's antics, antagonized participants, and end results are actual. For all Naapi's heroic moments or dastardly deeds-and there are plenty of both throughout the Naapi story cycle-a new definition of him and the energy he represents is essential. Redefinitions that reiterate the idea that Naapi is some sort of mythical god are not really innovative, descriptive, or accurate. They simply continue his misinterpreted character, not as the Blackfoot know him.

Interpreted through the lens of nature's elemental forces of creation, for instance, Naapi, like his Trickster companions, is constantly reborn, transformed, and reshaped into new and ever-evolving identities. He undergoes forms of immortality, reincarnation, and rebirth, which is why he represents a process of continual renewal that epitomizes the spirit of earth's new growth every day, year, and 
season. Indigenous Peoples understand such cycles to be part of Peoples' spirit and the foundation of human-and the universe's - nature. In common with other Tricksters, Naapi's regenerative powers are ever-developing and universal among the hemisphere's Indigenous Peoples:

There are countless Napi stories still in circulation. These vary greatly among themselves from the didactic to the "pornographic." Generally, they deal with the nittygritty side of life, not the lyric nor the romantic. Thus they reflect the many-faceted nature of Napi himself. He is the old Algonquin god, and appears as creator, trickster, thief, scoundrel, libertine, wise man, judge, nit-wit and the brunt of jokes. He is a culture-hero and messianic figure of the Algonquin peoples. His Blackfeet name Napi means both "old" and "white," and usually with the suffix -koan (person) the word is applied to the white man. Thus he reminds [us] of the Mexican Quetzalcoatl and may have the same origin. Such a figure crops up in myths from all over the Americas. Curiously enough, modern Blackfeet frequently call him redundantly "Old Napi" as if they had forgotten the true meaning of his Algonquin name. ${ }^{11}$

\section{STORY GATHERING}

A corollary to Naapi's free-flowing energy is that his stories have been recorded loosely and in mixed order, which was in accordance with traditional Indigenous storytelling norms; context either did or did not determine the appropriateness of a story. This means that for this study the story collection is very uneven because storytellers did not divulge everything they knew to every collector. Rather than assume that this is necessarily a feature of Naapi stories, it is worth considering the role of data collection, as people often share what they believe data collectors want to hear, what they believe they can handle, or what they have time to listen to or record. This is particularly true when stories are requested on demand and lack an interpreter. It is worth considering how this scattered style of story groupings could affect the order in which stories exist, either at the societal level of Indigenous Peoples' understanding for backgrounding and contextualization or in the experiences of individual storytellers, or both.

It is often argued that Indigenous Peoples could not have done better than to have scattered story collections, as "there was no strong priesthood to carefully preserve the stories and they were changed slightly with every telling. However, their framework remained the same, and the descendants of one group can sometimes be traced [to] the similarity of their folk lore [sic]." 12 This argument is only partially correct and generally excuses the ignorance of collectors; the Blackfoot have very strong, organized, and highly private associations in which initiated members learn 
stories about Blackfoot traditions. In addition, certain story versions were passed down through several generations of families. All Blackfoot ceremonial traditions are rooted in a story matrix, and Naapi stories are only one genre among many: "Indian legends are divided into two groups: the old tales and the new ones. The first group consists of all the 'golden age' stories in which animals can change into men and many supernatural events can happen. These are usually 'how' stories: how did the World begin? How did the Kingfisher get his lovely feathers? How were the Rocky Mountains made? These things could be explained only as works of wonder." ${ }^{13}$ Naapi stories answer these great mysteries. This is why the Blackfoot say they have been around since the beginning of time. It is also why the Trickster is referred to as a "lesser deity": "They were never attributed to one Supreme Being but to animals and lesser deities. The most popular of these gods was the Trickster, who performed miraculous feats purely for his own amusement. He has no counterpart in our mythology; he is one-quarter god, three-quarter devil. Here is a typical Blackfoot legend, telling of the creation of the world by the Old Man, or Trickster." ${ }^{14}$ This is, unfortunately, the best non-Indigenous interpreters could make of this confusing non-human, non-animal, non-God entity.

To clarify, stories do not always change at every telling, although some details have dropped out over the generations because of the outside religious and political pressure placed on the People to stop telling these stories. In addition, in many cases stories or details were left out because they were untranslatable. Some editing was done by storytellers to protect the stories; some would purposely leave out crucial sections or references. Other missing details were erased, including entire stories that were expunged from the record by non-Indigenous recorders who felt they were too problematic or even heretical. As such, commentary that is typical of the reductionist and simplistic views dominating generations of Naapi interpretations shows that Naapi stories are basically too advanced in concept, form, and epistemology to be handled by amateurs who claim expertise in them. Even Naapi's "Trickster" status is an oversimplified concept used to examine his escapades, apparent comedic tendencies, and exaggerated personality. For this reason, Trickster literature should be considered in any serious study of Naapi, as he appears as comparable personages in many Indigenous oral traditions, which justifies this book's consideration of a multitude of stories (see the appendix for a sampling) and perceptions of Naapi and entities like him, drawn from the stories as a body.

\section{SIGNS IN SPACE}

Another factor that influences interpretations of Naapi is that many analyses conducted in English, French, and other Indo-European languages are problematic in 
their efforts to understand the Blackfoot way of seeing and expressing the Blackfoot world. English, for instance, is commonly regarded by Blackfoot speakers as intensely limited in its ability to express or otherwise convey the relationship between place and person, especially compared to Blackfoot. As an Algonquian/ Algonkian language, Blackfoot is concerned with clarifying action, process, character, and quality, or the knowable personality of each Person/Being discussed. For example, the manner of a river's character reveals the personality of the landscape in relation to People. Status is accounted for by forms, sources, and energies, not by isolation or static representations. Spatial dimensions and other specifics about conditions are required in a Blackfoot world, where beings are known by the way they move. Questions such as what is it like, how does it go, where does it stay, and where does it happen are central concerns that emphasize spatial relations and movement as signals of vitality and life-giving forces.

Struggles, conflicts, or challenges are central protagonists in Naapi and other creation stories, and those who undergo them rarely involve humans but instead recall opposite-speak conditions. Those challenges that in translations appear to refer to humans actually do not. To the contrary, they typically refer to elemental or universe-level matches of energy (e.g., thunderstorms, tornados), but they are ascribed human-like attributes upon and as a result of their translation. Furthermore, these Naapi stories often describe something or someone who speaks or turns into human form, which reflects a world where Beings (e.g., rocks) have the power and will to make themselves known to humans, to be recognized by rather than as humans. This does not, however, "turn them into" humans in the Blackfoot experience. People can communicate and be understood by other Beings without meaning that Being is human-like. Other living Beings-elements, plants, animals-do not so much "turn into" humans as make themselves comprehensible to humans. This means they are intelligible because they are perceived, felt, and sensed with an intent to be understood, to make an effort to communicate. They are able to communicate as intelligible and intelligent Beings that have a soul and are worthy of respect and reciprocity.

In Blackfoot, as experienced through Naapi stories, being and becoming human means learning to be intelligible and intelligent with regard to other Beings and to be understood by others who share in the gift of spirit or can understand it. A fully realized human Person can understand and relate to other non-human Persons or Beings, providing the participants in the exchange are noticed and noticing - that is, communicating successfully. In the Blackfoot world, "animacy" refers to Beings who deliver messages to People because they want to communicate and want the People to comprehend. Such transformations or patterns of change and exchange, such as those the earth goes through, are evidence that People do pay attention. 
Land-based homeland formations-such as riverbeds, mountains, plains, valleys, forests, caves, and glaciers - create their own weather patterns, have unique terrains, and interact with flora and fauna in unique ways. Together they form the episodic and rhythmic rhyme and reason of the natural cycles on which traditional Blackfoot life has been, and in many ways continues to be, based. For example, whirlpool shapes are created in both air and water. Throughout the homeland, several sites created by the forces of that place at a particular time show their strength and unpredictability and reveal how these natural forces give them shape and power that defines their character. This is another expression of the respect the People accord them.

Similarly, the various shapes in and around mountains - such as basins created by avalanches - show the movement of snow and ice on a massive scale, caves' unique air conduction, the erosion of hillsides and riverbeds, and the kinds of rock that predominate in the area, as they all have Trickster stories that relate their ancestral and current activities. Earthquakes, caves, coulees, hoodoos, and sand hills are parts of the story of the People who live among them; thus they appear in Naapi's stories to teach People how to live completely. Spirits is simply a term used to describe the creative energies that reside in these places throughout the homeland, Naapi's energy in particular. The Blackfoot identify with each Naapi story; animals, plants, and places are traditionally appreciated for their valued traits, medicines, and the sustenance they give to the People, the subject of Naapi stories. Naapi shows People the highly esteemed species, climates, areas, times, or other Beings that have the power to transform themselves and adapt to the larger environment; all are co-creators.

Naapi, creator and main protagonist, shapes the homeland landscape and consciousness concurrently. Some of the notable strengths the Blackfoot absorb by observing natural cycles include adaptability, transferability, changeability, flexibility, transformability, generosity, foresight, honesty, attention to detail, respect for limitations and rules, persistence or perseverance, and gratitude, which are referred to in Blackfoot as "staying power." This expression refers to psychological, mental, and spiritual aspects of persistence and enduring challenges and hardship, physical and otherwise. The Blackfoot expression Mokakit ki akakimaat, meaning to be strong and persevere, is an expression learned from Wolf; it is a teaching about having staying power or stamina for life that differentiates between just getting by and thriving. The expressions "what goes around, comes around" and "we are all relatives" connect the People to the natural word, to the sky and cosmic realm, and to all living Beings sharing space, time, matter, energy, and the like. The Peoples' obervations and the stories that relate them connect weather patterns, animals' behavior, growth cycles, and forms of plants to ground Naapi 
stories in physical reality and identify ideal models of social and ethical behavior for the People.

Naapi's energy manifests as the architect of the space that others occupy. Naapi gives each meteorological, animal, plant, and human family its place in the homeland by opening up spaces to grow plants, medicines, and animals that provide for and offer protection to the People. His nature sets the pace and context. Life forces exist within the setting and land and within the Beings in it, life is presented to and interacted with by everyone, and ceremonies have concomitant spirit-locating processes, which are initially outlined in Naapi's transgressions and gifts and bind the People to the places where Naapi's episodes occur. Discrete site mapping and naming, however, fails to capture the extent of their intended meaning, as it is limited to specific land sites and to a noun-based space- and place-oriented project. It misses out on the dynamic, unpredictable, and encompassing aspects of Naapi's activity, which eventually omits all sorts of unmappable material (e.g., climatologic and meteorological phenomena such as winds and lightning) from analyses that focus too much on nouns or place determinants. Naapi stories combine distinct yet connected phenomena and descriptive and discursive patterns, which is how they are "speaking" to People. These are the many signs in space that communicate to the People. Even these signs are described in terms that focus on aspects of the movement of energy in ways that English, for instance, does not; wind is described as "going to" a direction as opposed to "coming from it."

These communications or signs require a response through ceremonial and spiritual involvement and commitment of the People, and this is what is meant by saying the People develop their consciousness along with the landscape. Naapi stories initiate the People into a similar consciousness and awareness of the potential unhelpful or hurtful effect that the mere act of living has on others. Practicing traditional Indigenous Peoples' ceremonial life based on such stories is itself an exercise in ethical and moral consideration. Through the reflexive meditation taught by Naapi's examples, other Beings become ourselves and vice versa. Naapi stories highlight moral principles that shape and restrain human behavior, but not as the human struggle against the confinement felt by being bound to place or even as strategies that demonstrate ways to transcend or disregard morality. To the contrary, Algonquian/Algonkian and Blackfoot "morality" is derived from and therefore defined by its contextualization within ecologically sustainable realities as wellsprings from which rules are born. These traditions assert and affirm the ecological limits placed on human excess, much of which originates with Naapi's examples, which model the sustainable limits of our own physical and spiritual health-albeit through the negative example of his outright denial of this imperative to refrain from living in the margins of excess. 


\section{PARADIGMATIC OPPOSITION AS KEY TO BALANCE}

In Algonquian/Algonkian and Blackoot traditions, the best teachers of ecological, physical, and spiritual balance are the environment and its myriad inhabitants-the animals, birds, winds, geographic features, weather patterns, and landscapes. Naapi experiences the entirety of creation as the foundation on which social rules and customs are built, exemplified as those whose lives supersede the ecological, physical, and spiritual breaking point. He takes the maximum that life can offer him and is still unsatisfied and restless. He takes all that the earth and everyone who resides on it can provide, is at the forefront in any act of consumption, and shows how taking more than is needed is a true source of death. The Naapi imperative is revealed through reflection on his devastating acts and by observing him and his actions in a turned-around form. To listeners of the stories, lessons are revealed in the complete opposite of his actions, attitudes, comments, and desires, as Naapi's detrimental activities demonstrate and encourage more conservative consumption and synchronism in relating to the energy of place. Naapi epitomizes the potential power for human destruction. He reveals that the preservation and sustainability of the earth's resources is beyond human debate or contests concerning social rules or customs, moral or ethical laws, or principles established by nature and that things already in balance can be altered by Peoples' maneuvering or manipulation. Naapi demonstrates that such meddling with the rules threatens ecological disaster, population demise, extinction, and other horrors. Naapi's escapades remind People that flaunting the rules of the natural world ensures our unnecessary daily struggles, such as being cold, hungry, or dying. These become protracted and extensive in their potential to affect the grand scheme of things.

In Algonquian/Algonkian and Blackfoot traditions, destroying, usurping, or otherwise manipulating food sources, for example, constitutes a first-degree crime. Naapi and his Algonquian/Algonkian equivalents teach that People may take from and use nature to help ourselves. We must, however, retain a level of humanity, awareness of the needs of all other Beings, and understanding that People will need those resources far into the future. The world is not created by humans; we are born into and sustained by it. Viewed through Naapi's adventures, regard for the entirety of creation is the basis on which societal rules and customs are built. The People are children of it; creation is our "relative" - a grandparent or parent or other kin. Excesses such as killing beyond one's need or inhibiting potential life in true Naapi style push beyond the tipping point of the ultimate provider, causing death. These matters are laws established by nature, over which human maneuvering has little and a mostly detrimental effect unless handled with great care. 
Algonquian/Algonkian and Blackfoot inclusivity functions in consideration of who belongs to the multiple families that are all intertwined in creation. It concerns itself with the stages of development of plants, birds, and animals and in all of these seeks parallels, comparisons, and contrasts with People. These details are how the human element of the People is revealed and defined; identifying People cannot be done without reference to these other dimensions of our shared world, so Algonquian/Algonkian social and cultural mores are based on exigencies set by nature's limits. Ceremonial life is modeled on ecological boundaries that simultaneously constrain and nurture while maintaining a connection to the vitals that replenish People. The misuse, abuse, and excesses of others are ultimately suicidal acts, since it is on such others that the People depend.

The land's spirit is not an object of imagination and ritual that Indigenous Peoples manipulate to guide votive offerings and ceremonials. To the contrary, the universe's obvious animateness informs Peoples ethical, moral, religious, and philosophical tie-downs by offering its truths of the natural world. This Indigenous metaphysics forms the core of countless ceremonial traditions that recall Peoples' interactions, observations, and experiences with nature. It is taught and recollected through Naapi's experiences that become the Peoples' mapping of the world passed down and codified in their linguistic, artistic, and cultural shorthand in story forms that shape interpretations of events and processes that may occur with more frequency or, more recently, with more intensity than is customary. The stories re-create a homeland specificity through precise toponyms that place Naapi virtually all oyer the land. These areas accentuate points of reference that all the People recognize, so Naapi, the land, and self-identity are all intertwined.

These observations and interactions encompass millennia and are encoded and told through story and other, accompanying artforms. These media traditionally recorded changes (e.g., in oral, material, and visual arts), from those that are instantaneous to those of longer duration-devoting particular attention to elements, shared space, or other Beings affected by changes. Naapi's transformations partner with co-creator powers' patterns founded by his parents Naato'si (Sun/Old Man) and Ko'komiki'somm (Moon/Old Woman), along with Naato'si's second wife, Ksaahkomm (Earth). Working together, they establish Naapi's archetype of his countless manifestations and myriad shapes and forms. They create the spaces that plants, medicines, and animals occupy, which establish the beginning of human residence in the land. These creations reveal the wisdom of the homeland, communicating wide knowledge of the mechanisms that make the earth's ecological, solar, and spiritual system work-all captured in Naapi's constant changeability, disruption of order, and changeability. 


\section{SIGN AS FIRST LANGUAGE}

The Blackfoot word "ksaabkomm, earth (personified),"15 is an animate noun, meaning it has the life energy that gives it "personhood" status and thus membership in the "we are all relatives" class, or part of the group with whom People have a Person-to-Person or Being-to-Being relationship and communication. As a shaper and communicator of the world, Naapi is based on the first speech known to the People: that which is left in the land as markers and communications and constitutes the Peoples' and other Beings' tracks. Ernest Thompson Seton reminded those hiking to "never forget the trail, look ever for the track in the snow; it is the priceless, unimpeachable record of the creature's life and thought, in the oldest writing known on earth." ${ }^{16}$ This is the oldest "writing" or system of communication, which both Coyote and Wolf used to convey messages to the People; they were read and understood by the ancient Plains Peoples and became incorporated into their way of life and thought.

For the Blackfoot, philosophy, literature, and environmental consciousness and conscientiousness are based in frequent interaction and very close proximity with nature and human character. The environment is a source of philosophy and a way of life. Having a focus on non-linguistic communication systems, such as trails and scent markings, enables People, animals, plants, and stars to be equal interlocutors/ communicators/speakers. This enables these other Beings to "speak" to humans and opens us to our relationships with them, making them our "relations." Indigenous Peoples interpret our lives as intertwined and intersecting with all our relatives. When we make time to listen and respond to all sorts of non-linguistic messages, we "speak" to the universe and know that we are heard, not just seen. When singing the early songs and telling about the early People, scholars should not limit themselves to the linguistic, since doing so emphasizes the awkward and unrealistic position of regarding human speech as more important than other forms of communicating - which, of course, it is not. If it were, we would never understand the universe; we would be inarticulate translators of the wisdom that resides in all our relatives who share the universe with us. Like Indigenous Peoples all over the world, the Blackfoot must be "multilingual" and know how to function in different modalities and contexts, which means understanding and integrating the nonverbal into our knowledge systems. These are not theorized, abstract commandments because the signs are real reflections based on the physical realities in the Plains Peoples' homeland. Plains Sign Language is

the method of communicating thought by means of signs [which] has been brought to such a degree of perfection among the plains Indians that any idea can be expressed as readily as if words were employed. Every want can be made known, 
questions asked, and stories or traditions told. The signs employed are very expressive, and usually convey an idea so clearly that no explanation is needed, even by one who has never seen them before. They are often so forcible that they give an insight into the Indian imagination which could never be conveyed by words. An instance of this is related by Captain W. Clark, of the United States [A] rmy, who made a long and thorough study of the sign language. He noticed that the Indians, in referring to the Milky-Way, made the sign of death and another sign for trail, and after much inquiry he learned that the Indian superstition was that the Milky-Way was "the direct and easy trail to the happy hunting-grounds made by those who had been killed in battle." In the sign language different races and tribes are designated by movements of the hands, referring to some real or imaginary characteristic. ${ }^{17}$

To the Plains Peoples, Plains Sign Language was inspired (i.e., "taught" = demonstrated) by the sky realm Beings (e.g., Sun, Moon, Stars), and it represents the strategies offered by nature, such as a star's "twinkle" as a demonstration of an intention to communicate. For example, Plains Peoples notice the "sign language" communicated by the twinkling stars of the Big Dipper and learn to read these signs as meaningful. Flashes of light are messages, sent with intent. They are signs: "TW IN KLE. Make the sign for STAR, and while holding [your] hand in that position snap index and thumb as in LITTLE TALK." 18 The movements of the stars and other sky realm Beings also "speak" using the first "sign language" in contrasts of light and dark. Sun and Moon, Naato'si and Ko'komiki'somm, establish this contrast between Sun's daylight rays and Moon's nocturnal light. To the Blackfoot, the stars are this pair's children, so it is fitting that they speak the same sign language. Blackfoot stars are named for their aspects, including whether they are flashy or have a tinge of color, are cloudy, or give the appearance of a scintillating or shimmering Being. To the Blackfoot, signs of light given off by the universe are a primary language, and the stars first taught the People that this is the original sign language. The essence of Plains Sign Language practiced by Plains Peoples is that it attends to nuances in shades of color, levels of opacity, and blinks or shimmers of light, however brief or faint. Stars and other flashing lights help People and send messages by blinking, so that we learn to interpret the communication system already extant and happening in the world, to send messages, to read, and to interpret the cosmos, animals, plants, waters, and their messages - none of it linguistic. This is how to hear and experience the spirits, the cosmic consciousness.

Plains Peoples' use of light information, such as flashes, as a method of communication is a long-standing tradition, especially applicable for situations requiring communication across great distances, such as during war or hunting party movement. Examples of alternating, blinking, or shimmering light and the absence of it 
in the form of shadow appear in Naapi stories as a principal technique employed by hunters to gain and retain animals' attention. Contrasting light/dark thus became an ancient first-order tool in Plains Peoples' communication systems, with many instruments. Some of these are based in naked-eye astronomy and observations of the astros using calendrical methods. Others are more immediately implemented with tools on the ground, such as rocks or shells, and in later times with mirrors, ribbons, and bright cloth.

On another level, interpreting tracks' meanings is analyzing information based on angles, shades, and subtle nuances in contrasts of light. Hand and other physical signs and gestures used for communication between People were perfected and widely practiced in Plains Peoples' lives. According to Blackfoot tradition, the People learned signs from the Sky People, particularly stars, as hand signs were developed and employed simultaneously in a context in which contrasts of light, coupled with sounds across vast distances, were recognized as signals to which birds and animals are attuned to respond. This system is based on the observation that if these Beings attended to the movements and lights of stars, this is communication, albeit non-verbal. Naapi stories also frequently reveal how using spoken words can destroy hunters' potential catches by scaring off game, thus the preeminence of sign usage. Songs, meanwhile, are noted as less disruptive than speech and sometimes even as helping to attract animals. Songs are thus used in hunting as a signaling system, often integrated with methods involving lights and intermittent flashes of color, depending on the animal whose attention was sought.

The Plains Peoples' experience, told in Naapi stories, is rife with interpretations and observations that are a result of the lived landscape shared among all the other Beings who were here before humans. One reason Naapi, as Trickster-travelercreator, occupies this position in many Indigenous Peoples' traditional creation stories is because of the non-verbal "language" he conveys through the signs he leaves in his wake. These long-since identified patterns are presented below with some possible interpretations: 


\section{“Coyote Trails and Possible Interpretations"}

Understep walk. Extreme rest: I have found this pattern around dens, especially when a coyote shifts from one bedding spot to another. Extreme attention/fear: This is also the gait used when stalking prey very slowly-like a cat. It could also be used to sneak away if the coyote felt at great risk and wanted to avoid detection. Exhaustion.

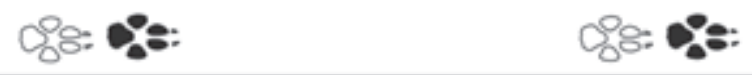

Direct register walk. This gait is more often a reflection of substrate or grade rather than mood or behavior. In deep substrates, coyotes direct register walk when traveling. However, Jon Young points out that in specific locales, coyotes use this gait to travel about. He explains that the potential dangers in an environment, such as a high density of cougars, influence when, where, and how coyotes move.

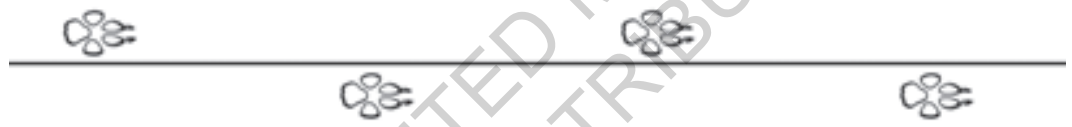

Overstep walk. This is the typical walking gait for canines. Exploration: Often coyotes shift from a trot to a walk when investigating and pinpointing any odor they cross in the woods. They'll walk around scenting out apples buried in early snow, investigating squirrel activity, and checking another coyote's scent post. Ease: Coyotes walk when they feel relatively safe, often in the company of others or in areas with good visibility or where scents carry far and well. They feel most at ease in the heart of their own territory. Scenting and communication: Coyotes may shift to a walk in order to scent, before moving on. A great deal of social exchange is done while walking, but many gaits are used. Movement in the immediate area of dens is usually done in a walk. Well fed: A coyote who is not actively hunting may walk. Caution: A cautious coyote walks.

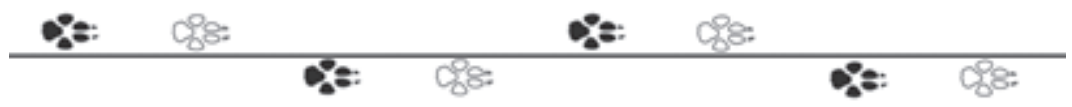


Understep trot. This is a rare gait. I have seen this pattern as a result of playing with others-like a slow prance.

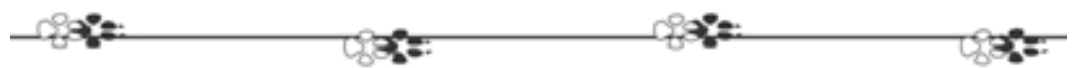

Direct register trot. This is the natural rhythm of the coyote. Hunting and patrolling: Coyotes move through their range in a trot. Awareness: Coyotes are actively investigating their surroundings in this gait. Comfort: ... Although the animal is keenly aware, this gait shows little stress or discomfort. This is the usual gait for moving about the home range.

Overstep trot. This is an uncommon gait for coyotes. Dominance: I have seen this gait used in pack communication on several occasions. I believe that the vertical "hop" of this gait may be involved in a visual communication of dominance. Stress: Dan Gardogui noted this gait and track pattern in females trying to keep up with the insatiable appetites of their maturing pups and in coyotes skirting wolf territories.

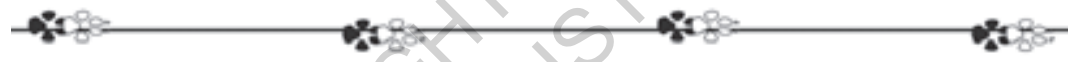

Straddle trot. In coyotes, this is a transition gait found only in short sections of trail. However, it shows that the animal is not alarmed or reacting to something in its environment, in which case a transition gait would be skipped altogether.

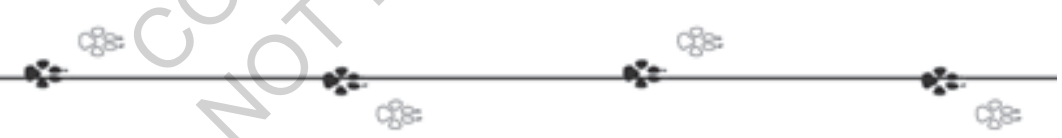

Side trot. Travel mode: This gait may indicate that a coyote has a destination in mind and has picked up the pace slightly. It is often seen on easier travel routes, such as beaches, roads, and trail systems. Increased awareness: This gait is often used when coyotes are exposed and away from cover or between areas of cover but not yet in full alarm. Trespassing coyotes might also pick up their pace when moving through another pack's territory.

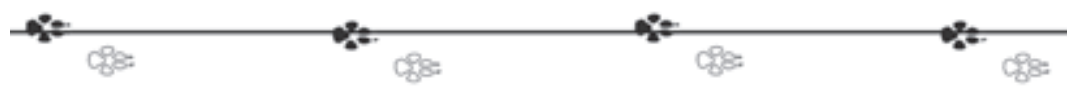


Extended direct register trot. Eager/excited: John McCarter reported finding this gait when coyotes had just found a carcass or a moose dying of brain worm or some other bonanza. The extended track pattern looks very much like the standard direct register trot, but the strides are nearly twice as long, often around 40 inches.

Slow lope. Play and communication: The "rocking horse" lope uses tremendous energy and is often found in coyote interactions. Sticks are sometimes picked up and carried for short distances in this gait. Motion is often erratic and circular. Hunting in tall grass: Jon Young has watched coyote use this gait while hunting cottontails in high grass. Safety: A coyote using the gait is not alarmed.

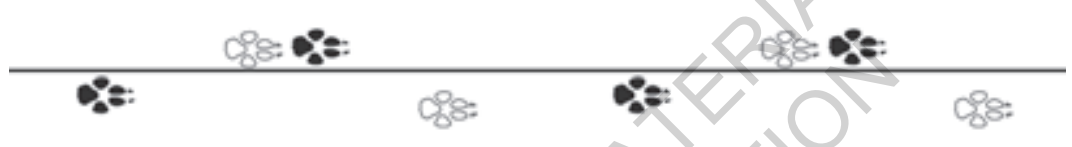

Lope. Discomfort and fear: The coyote has picked up the pace to move out of the area for some reason. A coyote may lope when it is exposed between areas of cover or when it is trespassing. Transition: A coyote that is not in immediate peril but still alarmed may transition from a trot to a lope to a gallop. Play/excitement: Often, faster gaits in mammal species show fear, but the same gaits can be interpreted in the opposite way. Playing coyotes lope, as do coyotes that are eager and excited-a similar interpretation to the extended trot. Hunting: Coyotes sometimes run prey to exhaustion, although this is more likely done at a gallop.

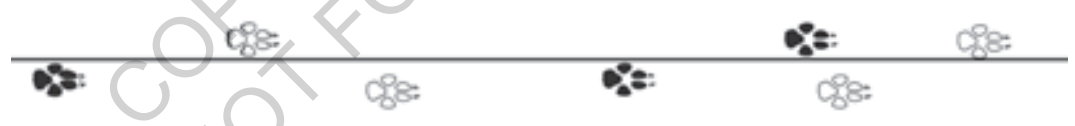

Bound. Alarm and fear: Frightened coyotes use this gait to move from stationary or a slow gait to full speed. Chasing: This coyote has just taken up pursuit of prey, a trespasser, or a playmate. Deep substrates: Bounds are also used to increase the speed of travel in deep snow-in this case, all four tracks are made in the same hole.

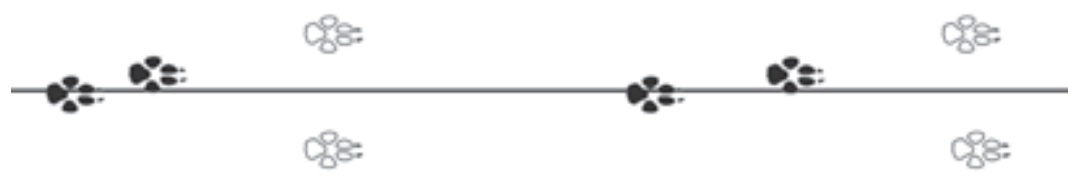


Gallop. Fear: Coyotes run from what they fear most. Hunting: Coyotes run down their prey, twisting and turning in pursuit. There is less time between footfalls than in the stretch gallop, allowing the coyote to react quickly to changes in direction

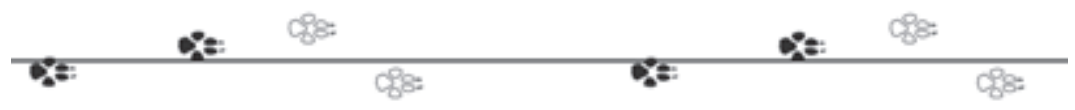

Stretch gallop. Extreme fear: This coyote has lowered its awareness of the area in exchange for putting distance between itself and a sound, predator, or location as fast as possible. Hunting: A coyote stretches fully and invests everything to capture prey, which in turn replenishes its energy supply. Most often, prey twist and turn when closely pursued, so it is difficult to maintain the highest speed through turns; look for regular gallops as the coyote closes in.

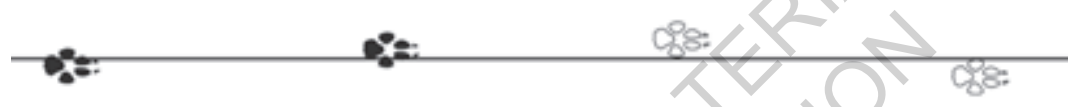

Patterns created by rolling, lunging, attacking, holding onto prey, or other specific behaviors, as well as the various interpretations of coyotes in varied habitats and conditions across North America[,] must be learned in the field and with experience. ${ }^{19}$

The complete list of Coyote's trekking patterns is presented here because a sampling does not show the great range of "signs" Coyote conveys. That said, there may be more we do not know about. Those listed here demonstrate Coyote's advanced level of communicative ability, since other mammals' gaits are not perceived to give away as much information. Large game animals, for example, may only leave four or so identifiable "signs" that might be read consistently. People "reading" Coyote's paw prints to determine what the animal feels, knows, or intends receive a basic lesson of land-based knowledge in how to connect patterns to increase understanding. Beyond the physical messages left in prints, efforts to decipher the meaning of all the multiple types of messages that are out there to be discovered and decoded can include studying broken sticks and branches, chewed leaves and grasses, scat and urine markings, and scratchings and tears into trees or dirt that identify occupation or territories. It is important to offer a sample of the types of analyses Indigenous Peoples traditionally undertook all the time as part of everyday understanding. These are just the physical aspects. Hunters occupy a deeper level of understanding of animals' intentions through the practice of getting into another's footsteps by interpreting and following their tracks. Hunters need to know how to occupy the heart, mind, or spirit of the animals sought, and they use their tracks' communications to do so. 
Naapi or Coyote or Naapi as Coyote means Naapi is a great traveler and a particularly smart hunter because Coyote goes everywhere and is constantly on the move, and he gets his prey. As he moves into new territory, he learns about the as-yet unknown and becomes a pioneer who is forever seeking new knowledge to communicate. This is what the focus on his footsteps is about; he is a fluent, even masterful "speaker" in sign. To the Blackfoot, his pursuit of knowledge and new terrain and its conditions, occupants, and patterns of life includes Indigenous Peoples. From this perspective of Naapi as Coyote, he is a great conveyer of non-verbal information. He is a consistent traveler in the physical sense and in the spiritual sense on the journey to learn new metaphysical realities. He is on a perpetual vision quest, always the seeker, as he explores uncharted territory, on land and in the metaphysical. Blackfoot oral tradition is based on these types of messages, and the better one is at capturing their range, the easier it is to understand Naapi.

\section{CONTEXT AND SPACE DETERMINE MEANING IN BLACKFOOT}

The Plains, with its wide open spaces on which it can be difficult to hide, is the space, the backdrop against which Plains Peoples and the other Beings in their midst communicated since ancient times, leaving their mark on the Blackfoot language. John MacLean (1898) explains that in the Blackfoot language, nouns are shaped by the elements or quality they consist of or create, and gender - that is, the distinction between animate and inanimate-organizes those things that are considered to be alive in the animate category. These are "trees, plants, and various objects of vegetable nature [and] nearly all names of implements, ${ }^{20}$ so that tools and technology are considered to be alive, to have the force of life within them. Beings related to the life forces in the Indigenous cosmos, such as the astros and rivers, are classed as animate as well: "Natos = the sun. Omuqkatos = the great sun. Kukutos = a star. Kokumekesim $=$ the moon. Neetuqta $=$ a river. Natosiks $=$ suns, also moons and months. Kukutosiks $=$ stars. Kokumeksimiks $=$ moons. Neetuqktaks $=$ rivers $\ldots$ The Animate Nouns form the plural by adding $k s, i k s$, or $s k s$ to the singular ... Inanimate Nouns form the plural by adding ts or sts to the singular." ${ }^{21}$ Things that are considered animate move, make, or give signals or signs, otherwise known as making "talk" or communicating. An interesting element of this list is that all of the beings noted above are from the sky realm except the rivers, at least one of which is understood to flow into the sky by way of the Milky Way. Ultimately then, the river takes its own spot where it is at home in the sky. This is one example of the flexibity of context in terms of determining animate versus inanimate gender; just as there is no neat separation between the sky realm and the underwater realm, there is no neat separation of noun and verb or of animate and inanimate, since these conditions move with 
(i.e., in relation to) the speaker. People live on the earth, between the underwaters and the sky waters. Animate entities' interactions with People determine their level of animate energy and include some places, rocks, hills_land sites. While knives, axes, bows, arrows, and guns are tools for survival, so are powerful stories. Places affiliated with creation or creators, such as Katoyis (Blood Clot) and Katoyissiksi (Sweet Grass [Pine] Hills), are animate; as tool or person, both are life protecting and life preserving.

Blackfoot also distinguishes between the different actions of humans or other Beings within a given context and the actions inherent in or occurring within certain contexts. This separation acknowledges the Peoples' impact on a place and demonstrates Blackfoot's ability to convey keen awareness of each entity, grammatically identifying it with action and respect. Every living Being has unique perspectives and experiences, if not exactly a separate identity. The difference between human actions and those of other animate and living and active Beings is crucial; it is not so much a separation between the human and others as a tally of interactions by both that is of interest. Their relationship is explained by identifying their separate contributions to it and by negating binaries between the two by focusing on shared qualities, so it is essential to know who does what. These distinctions are so nuanced in Blackfoot and nonexistent in English that translations in this area often fail.

One way this relationship dynamic is addressed is by considering how all action happens in relation to space and direction, to deixis, and within a particular place. A deictic word refers to "a word, the determination of whose referent is dependent on the context in which it is said or written." 22 For a Blackfoot speaker communicating in Plains Sign Language, for instance, east is implied to be the direction the speaker is facing, which in turn defines left (i.e., northward) and right (i.e., southward) in signing, or that which the expressions or word pictures are doing or describing. This means that the delineation, definition, and use of space defines meaning; it could not function without an acknowledgment of the role space plays in the Blackfoot use of Sign Language, since it depends on it as a foundation on which to make meaning at all. Blackfoot verbal forms follow similar requirements or allowances.

Blackfoot speakers, in telling a Naapi story for instance, can also differentiate space from action, clarifying the difference between terrain and users of terrain. That is, if terrain can be animate, then it has will, intelligence, or intent, which is accounted for in Algonquian/Algonkian languages; they form a dual pattern of semantic categories between the ways they express land and what one does there or what takes place there. This is a crucial point regarding Naapi, since he simultaneously exists outside particular locations and everywhere at any moment. He also has a key role in creating and defining certain spaces by his actions in them. Naapi is thus both a Being and a creator of place, and understanding him requires that one 
knows this. With such divisions, "these underlying categories define a natural division between terrain, including the waterways themselves, and the life associated with it." ${ }^{23}$ Blackfoot speakers can differentiate and separate humans' actions that are taking place within a context from talk of the context itself.

One way this is revealed is in Naapi's travels along waterways. When Naapi encounters People or other Beings, he often does so as he emerges from or takes refuge in a source of water. Following Naapi's singular or numerous encounters with others, he returns to the water element, in the sense of either entering it or becoming it. Throughout numerous Naapi escapes, water is thus the method of transportation as a way of transformation. This use of the water element, with its many forms (e.g., liquid, solid), can become a deictic demonstrative, making it an excellent example of the ways the Blackfoot use Naapi stories to refine a distinction among those Persons or Beings who are from certain areas, the land, and the Blackfoot People. In this context, "areas" can include fluid, transient, inconsistent, highly variable conditions; and this is key to Naapi's characterization as fickle or impulsive because he embodies these changes, as much as is possible for someone who has no body. A sample of some of Naapi's arrivals and departures through this energy source is listed here, with examples of how Naapi's actions shape and make places: "eno-kimi 'long lake': eno- 'long', -kimi lake' . . awy-kimiska 'the lake that runs up and down': awy- 'running', -kimi- lake', -ska collective suffix . . . amiskapo?omakaty 'big south river': amiskapo- 'south', -omaxk- 'big', -axtai 'river' . . aka-oto-tughty 'many rivers': akau- 'many', -etaxtai 'river'? . ponokaisisaxtai 'elk creek': ponokai'elk', -sisaxtai 'creek' ... mo-ko-un-se-te-ta 'belly creek': mokuan 'belly', -sisaxtai 'creek." ${ }^{24}$ In other instances, names reflect what happens to People or Persons in certain places: "Oh-ty-nehts-ope-piney 'where we were drowned' cf. it-ni-inetsi-opeotspinan: it- . . ope- 'where', -ni- 'we exclusive', -inetsi- 'drown', -otspinan passive ... mastowisto-ek-oka-pi the lodges with crows painted' ... maistoikokaup 'crow-birdlodge."' 25 Throughout Naapi stories, Naapi acquires new names to fit his current condition in that setting and at that time, which it is understood may not have another appropriate occasion to be used.

With these examples, the message is that "by understanding the ways the world is discussed and thought about, it is easier to understand their use of toponyms, and we can learn how languages crystallize the spatial dimensions of experience and imagination." ${ }^{26}$ In Blackfoot this is not really a binary contrast between places and persons, since the actions of animals in a place are what form it; hence the expression for "elk creek," noted above as a way to specify that something happened in, resides in, or frequents a specific place. This is one definition of a relationship between Beings and place. This enables speakers to discuss different actions People or other Beings take in, upon, or around a particular context, as well as the already 
extant actions occurring within the context-a distinction that acknowledges their impact on a place and shows respect for each entity within that place. Peoples' actions are different from those of other animate and living and active Beings, so while they are acknowledged as integrated with and responsive to one another, they are identified separately. The focus is not on demarcations of opposition between the two, although analyses conducted in any of several Indo-European languages might confuse them. For instance, English has a limited ability to express or make a relationship between place and person, especially compared with Algonquian/ Algonkian languages. Blackfoot clarifies the character and quality of each "Person" discussed, of each terrain. In the examples offered above by Eugene Green and Celia M. Millward (1973), the manner of the river is key, so that the character of the landscape in relation to humans becomes known or is revealed. Blackfoot terms not only lay out pertinent spatial dimensions, they include specifics that are required in a world where everything is known by the way and where it moves.

Naapi's frequent water travels are yet another area where confused or unclear translations make a world of difference. Many translations describe Naapi as traveling "by" (i.e., "via") water; other translations have him traveling "by" (i.e., "next to/near") water. Muddled interpretations cloud readings and interpretations of Naapi stories, even though both or either reading could be correct depending on the Blackfoot speaker's intended emphasis on deixis, spatial relations, and movement. There is a difference between Naapi traveling by being in the water versus his walking along beside or around it. Once again, however, a native English, Dutch, or French speaker who knows neither Plains Sign Language nor Blackfoot will be unlikely to determine which of these meanings is correct; considering such nuances is unexpected, hence they remain unexplored.

The context in which Blackfoot speech occurs is such a crucial part of expression and determining meaning that the combination of multiple valencies with some transitive verbs can create confusion when translated into English, which is complicated when compared to corresponding terms in English: "The semantic indetermination of these categories, however, is more pronounced, since each of them covers a much wider semantic spectrum than the English subject... [An example is] the existence of transitive verbs with 'atypical' valency frames, such as receive, which disrupt the common correlation of the English subject with the semantic roles of agent or experiencer in the transitive clause; for if the verb stem did not provide any information pertaining to the semantic roles of its valency-bound participants, there would be no way of interpreting the subject of receive as a benefactive." ${ }^{27}$ Because of their flexibility, Blackfoot verb valencies and "to be" status forms produce multiple possible interpretations, which makes the Blackfoot language difficult for non-native speakers to use properly. When it is used properly, this same 
quality is responsible for the language being pointedly precise when creating referents. Blackfoot speakers have multiple options in the construction of new phrases and meanings, depending on how the features of space, relationship, and context are worked.

In his discussion of the person indexing system, Donald G. Frantz explains yet another way space and relationship are described in the Blackfoot language, ${ }^{28}$ which is reminiscent of Christopher C. Uhlenbeck's distinction between centrifugal and centripetal motion. ${ }^{29}$ The animate-inanimate distinction is what drives grammatical hierarchy, which is sometimes a comment about relative life-force energy, making speakers powerful and their speech full of life-enhancing or life-deterring forms. Knowing when this is the appropriate interpretation depends on several factors, many of which relate to the context in which the thing is being discussed and on whether that context infuses it with meaning.

As will be discussed in more detail in further chapters, the animate is rather complex in Algonquian/Algonkian languages and not because it is misunderstood by speakers, which is still, unfortunately, a popular academic argument. Rather, this perception is a result of the fact that translating the animate into English or explaining Algonquian/Algonkian grammar in English is difficult because of the limited ability to accurately render meaningful categories in the latter language. European linguistic traditions unintentionally obfuscate attempts to achieve clarity in Algonquian/Algonkian languages because they are radically different in their structure and their ability to produce or render accurate and meaningful translations.

A brief example of the person indexing abilities of Blackfoot versus what the European context provides demonstrates why this is so. In Blackfoot,

The basis for the person indexing system beyond second person is the classification of all animate and some inanimate participants (other than speaker and addressee) of a discourse as primary, secondary or tertiary. These, all classed as third person in terms of Indo-European semantics, have been called third, fourth, and fifth persons (or proximate, obviative, and subviative by Algonkianists). In this discussion I shall refer to the following persons:

$$
\begin{aligned}
& \text { first person = speaker } \\
& \text { second person = addressee } \\
& \text { third person = primary topic } \\
& \text { fourth person = secondary topic, subordinate to third person } \\
& \text { fifth person = topic subordinate to fourth person. }{ }^{30}
\end{aligned}
$$

One critical way analyses of Blackfoot linguistics help to comprehend Naapi is that the social structures he helps define throughout the stories are drawn from formations observed in the natural world, whether they are clouds, plants, mountains, 
herds, or a number of other possibilities. The excerpt above illustrates a great example of this; the leaders of the discussion occupy the first and second persons' roles, and together they are reminiscent of the two leaders of a Wolf pack on a hunt. The principal action involves two chief players who initiate the action, and others take part by following their lead, each in accordance with his or her rank. Blackfoot speech is based on observations of such leadership, and in this instance that dialogue (by signed actions) is initiated or established by the first and second persons whom Blackfoot observers identify as leaders. In the Wolf context it is initiated by the alpha, where "dialogic" action, even if just physical, is taken or begun; dialogue-like sign language-does not require speech and focuses instead on movement in space. This example can begin to show how in traditional Indigenous communication systems, bearing witness, participation in storytelling, heraldry, coup counting, and a number of public speech acts including prayer encompass the dialogic and include listeners as participants, albeit sometimes distant ones. The overall structure is similar to that of the Wolves in pack formation. It is interesting to note specifically that many Indigenous traditions credit hunting, coup, courting, and prayers' efficacy to Wolf. The Blackfoot observe and integrate a great deal from nature's Beings, and Wolves are considered great teachers in part because of their communicative practices that Blackfoot and other Indigenous Peoples adopt, which is attributed to their extraordinary acumen.

Naapi stories are microcosms; they are expressions of Blackfoot animate/ inanimate forms of grammatical gender distinctions that are fluid categories of spirit, activity, and community action that are graduated or otherwise expressed as degrees on a continuum and are changeable. In this framework, time, too, is nonlinear. All times are present at all times, and our experiential connection with a space and place marks the story of our being here. People's lives, names, and stories are meaningful because they bear witness to our presence and relationship to place. It's a symbiotic relationship, and we are who we are because we are where we are when we are and vice versa. Like Naapi, the Blackfoot mark the earth, leaving footprints, camping sites, remains, and stories in places. 